\title{
AN INSIGHT INTO RECIDIVISM AMONG MALE AWAITING-TRIAL YOUTH OFFENDERS AND THE IMPLICATIONS FOR PRACTICE
}

\section{T Gxubane}

\section{INTRODUCTION}

Recidivism among young offenders is a major concern for society in general and a challenge for all the helping professionals working within the field of rehabilitation of young offenders. Early therapeutic and statutory interventions with young people in conflict with the law are primarily focused on their rehabilitation. The high rate of recidivism among young offenders leads to questions about the effectiveness of the therapeutic and statutory interventions available to them. The ineffectiveness of early interventions with young offenders calls for an understanding of how these young recidivists experience the world around them. An underlying assumption is that a good understanding of various factors that young recidivists believe contribute to their reoffending will help to guide and inform early therapeutic and statutory interventions designed to help them and their families so as to prevent re-offences from occurring.

This paper will focus on the following variables which have been identified as playing a significant role in rehabilitation and recidivism among male awaiting-trial youth offenders:

- Age;

- Substance abuse;

- Sources of income and maintenance;

- Criminal histories and activities;

- Social work services and previous rehabilitation programmes;

- Motivation to re-commit crime;

- Solidarity with friends and peer pressure; and

- Re-integration into the commuity after their release from previous detention.

The research design and methodology that were followed in the study are summarised, followed by an outline of proposed recommendations to deal with the problem of recidivism among young offenders. For the purpose of the study, recidivism was conceptualised as the general habit of young offenders to relapse into crime, despite having gone through rehabilitation programmes during their previous period(s) of detention while awaiting trial at Dyambu Youth Centre. The setting where the research was conducted is a centre that caters only for awaiting-trial male juvenile offenders.

Dyambu Youth Centre (DYC) is the biggest secure care centre for youth in South Africa and accommodated around 300 awaiting-trial children and youths in conflict with the law during the period of 2001-2002, when the research was conducted. DYC is contracted by the Gauteng Department of Social Services and Population Development to operate as a secure care facility for youths in conflict with the law who have been designated by various juvenile courts around Gauteng to await trial whilst investigations on the alleged charges are carried out. It is situated in Mogale City, previously known as Krugersdorp, on the Gauteng West Rand. A private South African company, Bosasa (Pty) Ltd., previously known as Dyambu Operations (Pty) Ltd., operates the secure care facility.

Rehabilitation programmes at DYC begin with a compulsory introductory two-week life-skills programme for all the new inmates. Other rehabilitation programmes at DYC include: "Who am I?", which is a personal awareness and growth course, leadership training, alternatives to violence training project (AVP), biblical studies, basic literacy and numeracy training based on the adult 
basic education and training (ABET) model. The skills training and development workshops include: computer training, electrical training, arc welding, glazing, arts and crafts, motor mechanics, carpentry, plumbing, catering and sewing. Each juvenile admitted to the centre will be exposed to some sort of intervention aimed at their rehabilitation, depending on their interests and length of stay in the centre.

\section{RECIDIVISM}

Research conducted on recidivism in South Africa is limited. Most studies on recidivism have been conducted overseas (Largan \& Levin, 2002; Beck, 2001; Maltz, 2001; Brown \& Pratt, 2000; Copas \& Marshall, 1998; De Jong, 1997; McGuire, 1995; Martinson, 1974). The findings of these studies cannot be easily compared to those from the South African context, especially with regard to young offenders. South African studies on recidivism (Schoeman, 2002; Prinsloo, 1995) focused on a broad general offender population who have served time in prison or whose parole agreement has been revoked. Of some relevance to the study are NICRO1 studies, even though these studies mainly concentrated on efficacy of diversion in deterring young people from reoffending (Muntingh, 2001; Wood, 2003) and others had a specific reference to young sex offenders (Baptista \& Wood, 2002; Berg, 2004).

Various writers differ in the way in which the social phenomenon of recidivism is conceived, formulated and calculated. In technical terms, the recidivism rate of inmates released from prison is often calculated by adding the number of releases who are arrested for new crimes and the number of those who are sent back to prison, and dividing that number of "failures" by the total number of released inmates (Conklin, 1995). Whilst it is a common practice to measure recidivism according to re-arrests of offenders, Conklin (1995) points out to a major problem using such measurement. He states that ex-convicts who commit crimes are not always reported to the police and, on certain occasions, even if they are reported, the police do not arrest them. Beck (2001) proposed three guiding questions that need to be examined in developing a good understanding of recidivism. These are: (1) What needs to be considered as recidivism? (2) What is an appropriate time frame for recidivism? and; (3) What is the basis for making sense of the information on recidivism?

Barlow and Ferdinand (1992) highlighted some of the complexities in defining the concept of "recidivism" in relation to juvenile offenders, which they termed "chronic juvenile delinquency". There is some confusion about how many offences should have been committed, what offences should have been committed or how many convictions the juvenile offender should have had in his or her criminal history in order for an individual to be classified as a "chronic delinquent". Added to the confusion are the interchangeable use of the words "chronic" and "career", and the duration of offending. A "career", according to Barlow and Ferdinand (1992), implies that the juvenile delinquent has a recognisable identity and certain perspectives regarding criminal behaviour, as is true of some persistent recidivists. Some writers apply the term "chronic" to juvenile offenders whose criminal activity spans three to four years, whilst others look at the number of arrests and do not consider the duration of criminal activities (Barlow \& Ferdinand, 1992).

Sherman, Gottfredson, MacKenzie, Eck and Bushway (1998) endorse the use of valid risk assessment as a means of identifying offenders for whom "targeted intervention" may be effective, because certain offenders see their crimes as rational and conscious efforts to solve problems

1 The National Institute for Crime Prevention and the Reintegration of Offenders is a major nongovernmental organisation charged with the provision diversion programmes to youth offenders in South Africa. 
confronting them at a particular time. As such they often deny that they need treatment (Conklin, 1995). Ineffectiveness of rehabilitation programmes for young offenders presents a major challenge for practitioners working with young offenders.

\section{REHABILITATION OF YOUNG OFFENDERS}

The traditional approach to the rehabilitation of offenders is to encourage them to gain an insight into causes and consequences of their problematic anti-social behaviour through counselling. However, counselling is seen to be effective only if it results in lower recidivism rates (Lesser \& Braswell, 1987). Yochelson and Samenow (cited in Conklin, 1995:144) caution practitioners who work with young offenders to take note of "errors of criminal thinking". These include chronic lying, a view that other people's property is their own, unrelenting optimism, great energy, intense anger, manipulativeness, and an inflexibly high self-image.

It has been noted by a number of writers in the field of juvenile offending, including Thompson and Bynnum (1991) and Barlow and Ferdinand (1992), that a large number of young offenders, even though they are at a school-going age, choose to stay out of school due to their lack of interest in schooling. Some are actively involved in criminal activities, whilst others are looking for jobs or are attempting to establish small businesses as a way of generating an income. It is generally assumed that young people resort to crime because they cannot find jobs and are not employable because they lack marketable job skills. Hence there has been more emphasis on skills training rehabilitation programmes, since unemployment in South Africa has been severe among young people under the age 24 (RSA White Paper for Social Welfare; 1997). However, it is noted with interest by Krost (quoted in Conklin, 1995) that offenders often exploit programmes that are developed to help them. In other words, criminals with job skills end up using these acquired skills to venture into new avenues of crime.

Masters (1994) seemingly endorses the risk-assessment model of practice when she questions the very treatment given to offenders as perhaps doing more harm than good when counselling is forced on those who are not predisposed to it. Practitioners need to be careful with regard to deterministic models of assessment. These may serve as self-fulfilling prophecies to the potential clients, thus discouraging them from changing their attitude and behaviour. Copas and Marshall (1998) support the view that risk-assessment models provide only a description of the correlates of risk and not an explanation of the causes of risk or predictions about clients.

An earlier study report by Martinson (1974) contending that "nothing works" in the supervision strategies and treatment programmes of juvenile offenders sparked a major debate amongst professionals working within juvenile offending. Gendreau and Ross (1984) argued that perhaps a starting point should rather be a clear definition and goals of treatment before any conclusion is made regarding the effectiveness or ineffectiveness of any treatment programme. Fine (1996) seemingly concurs with Martinson (1974) that "nothing matters" for young offenders and hence "nothing works" in their treatment. According to Fine (1996), young people at risk have a certain way in which they think about themselves and the world around them, which could be described as "nothing matters". That is, if nothing matters, what difference does it make whether they go to school or commit a crime? They operate on the principle that if they don't matter, no one matters, nothing in life matters and therefore nothing in the world matters (Fine, 1996). This thinking about themselves and the world around them occurs long before they come into contact with legal processes and before they arrive at institutions. They are trapped inside a prison cell of their own minds well before they actually come into conflict with the criminal justice system and institutions that work with it (Fine, 1996). 
The focus of interventions for those working with young people at risk in the institutions, according to Fine (1996), is to support young people by helping them transform the way in which they think about their past, their present and their future. For him, it is their past that has made them conclude that they don't matter and that nothing matters. Therefore, for effective interventions to occur, such interventions need to focus more on "transforming" the young people rather than "changing" them. Fine (1996) emphasizes that the process of transformation is a cooperative partnership and not an operation which one person performs on another.

Fine (1996) distinguishes between the processes of "changing" and "transformation" of a young person at risk. For him, change is superficial and usually yields short-term results because it is an external phenomenon. On the other hand, transformation provides young people with an opportunity to alter the way in which they see themselves and the world around them. It provides young people with the structure and support within which they can grow and develop and ultimately transform themselves. Therefore, transformation is more of an internal phenomenon. Hence it is more likely to produce long-term results that are sustainable which can transform the manner in which the young people see themselves and in the manner they live their lives (Fine, 1996).

A primary goal in working with children and youth at risk, according to Brendtro, Brokenleg \& van Bockern. (1990), should focus on fostering self-esteem amongst the young people. They maintain that "(w)ithout a sense of worth, a young person from any cultural or family background is vulnerable to a host of social, psychological and learning problems" (Brendtro et al., 1990:35). The four basic components of self-esteem as originally identified by Coopersmith (1967) are significance, competence, power and virtue. These components are translated by Brendtro et al. (1990) to four central values in a unifying theme for working with children and youths at risk; these are belonging, mastery, independence and generosity. They consider the four central values as constituting a circle of courage in the development of any child or youth. Brendtro et al. (1990:46) argue that without the four central values that form the circle of courage "there can be no courage but only discouragement".

Discouragement is courage denied. When the circle of courage is broken, the lives of children are no longer in harmony and balance" (Brendtro et al., 1990:46). The seeds of discouragement outlined by Brendtro et al. (1990) are: destructive relationships, climates of futility, learned irresponsibility, and loss of purpose. It is emphasized by these authors that, if the helping professionals want to be successful in reclaiming children and youth at risk, they need to be able to identify where the circle of courage was broken before they can intervene in the child's life. They summarise: "One cannot mend the circle of courage without understanding where it is broken" (Brendtro et al., 1990:46). They highlight the importance of "de-coding" the problematic behaviour with which the child or young person is presenting. Effective treatment of children and youths at risk requires therapists to discover the meaning behind the problematic behaviour that they are presented with rather than responding to the surface problem behaviour (Brendtro et al., 1990).

In addition to financial costs and benefits of effective treatment programmes on juvenile offending, Ferrara (1992) has outlined other advantages, which can manifest in different ways. A juvenile offender who does not recidivate finds value in improved quality of life and instead becomes a productive member of the society. Some general characteristics of effective treatment outlined by Ferrara (1992) include the following:

- Clients are matched to appropriate treatment programmes since clients will be at different places along the continuum of delinquency;

- Staff members are adequately trained in their areas of interventions; 
- More than one agency becomes involved in providing services; and

- Multiple interventions are used in a single programme.

Curtis (1989) proposed that an essential role of therapists working with children and youth in conflict with the law is to find various ways of involving the most important figures in the lives of the youngsters and to identify features in society that aggravate their problem. A "juvenile liaison panel", according to Curtis (1989), is the systematic way of working with significant others of the child like the parents in a range of support activities, including linkages to alternative sources of shelter and parenting skills where necessary. She argues that it is futile to take children away from their community and return them without any new equipment to deal with their old problems. If they are not helped in that regard, they eventually remain "victims of the circumstances; poor housing, poor education, poor leisure facilities, poor employment prospects, [and] few choices in life" (Curtis, 1989:08).

\section{RESEARCH DESIGN AND METHODOLOGY}

A scholarly enquiry was initiated by the author whilst working as a social worker at DYC over a period of some six years, where the problem of recidivism among young offenders was identified. The study did not only explore an area that had never been researched at Dyambu Youth Centre, but aimed to describe it as well. The study adopted a quantitative methodological design as the primary method of enquiry combined with some elements of qualitativeness to accommodate respondents' views, opinions and attitudes. An interview schedule was constructed in advance and administered by the author in a face-to-face interaction with each respondent. The research questions were specific and remained constant throughout the period of investigation. Therefore, according to the Tripodi, Fellin and Meyer categorisation (1972), the methodology fell under the sub-type of [quantitative] exploratory-descriptive research design.

The quantitative data were converted to frequency percentages and presented in tables, graphs and other forms of illustration in a self-explanatory manner (Browns, McDowell \& Race, 1995). The qualitative data provided crucial information on the views and attitudes of the respondents that helped to supply new insights into the variables under the investigation (Grinnell, 1993). A combination of qualitative and quantitative data for analysis has been described by De Vos (1998:359) as "theoretical triangulation", which means " the use of several frames of reference or perspectives in the analysis of the same data".

The target population for the study consisted of all the male juveniles who had awaited trial in a youth detention facility, and had allegedly re-offended and were currently awaiting trial at Dyambu Youth Centre during the period of the investigation. They were seventy-five (75) in total. A quarter $(25 \%)$ of the population was considered adequate to form a core sample. Therefore, $25 \%$ of 75 being 18.75, the figure was rounded off to the nearest value of 20 respondents, for effective statistical data analysis.

A proportional, stratified random sampling approach was followed in the study. The researcher believed that a sample drawn from different racial strata would not only make the sample representative in terms of different racial demographics of the entire population, but would also help to shed light on how different racial groups experience the phenomenon under investigation. Therefore racial distribution was made up 50\% African, $30 \%$ coloured and $20 \%$ white respondents.

The researcher anticipated some threats to internal validity of the findings, since the respondents had known the researcher as a social worker at the setting where the study was conducted. According to Grinnell (1993:216), "Hawthorne effects" refer to the awareness of subjects that they 
are participating in the study and in turn try to give socially acceptable answers. The researcher acknowledged the challenge and found ways of dealing with it so as to overcome it. The researcher clarified the researcher's role that he assumed in the study and distinguished it from that of a social worker in the centre. This was done right at the beginning, when consent for participation in the study was negotiated with prospective respondents. The purpose of the study and that of each research interview were clarified once again before each interview commenced so as to create a common understanding and avoid false expectations on the side of the respondents.

The challenge in turn yielded a positive benefit for the study, since juvenile offenders often take time to develop trust in helping professionals. They usually try to ascertain whether the helping professional is "on their side" or on that of the judiciary system. Fortunately, the researcher had developed trust and good rapport with the entire population of juvenile inmates. Therefore respondents clearly understood the purpose and the long-term benefit of the study. They participated voluntarily and did not expect any favour in return. They were open and honest when assured that none of the information that they shared would make them identifiable or be divulged to the court or used against them.

\section{DISCUSSION OF THE MAIN FINDINGS}

It should be noted that race differentiation as a category did not have any significance to any of the variable(s) that were under investigation. All the key findings, trends and patterns of recidivism were prevalent in all racial groups that formed the sample.

\section{AGE FACTOR}

FIGURE 1

AGE ANALYSIS

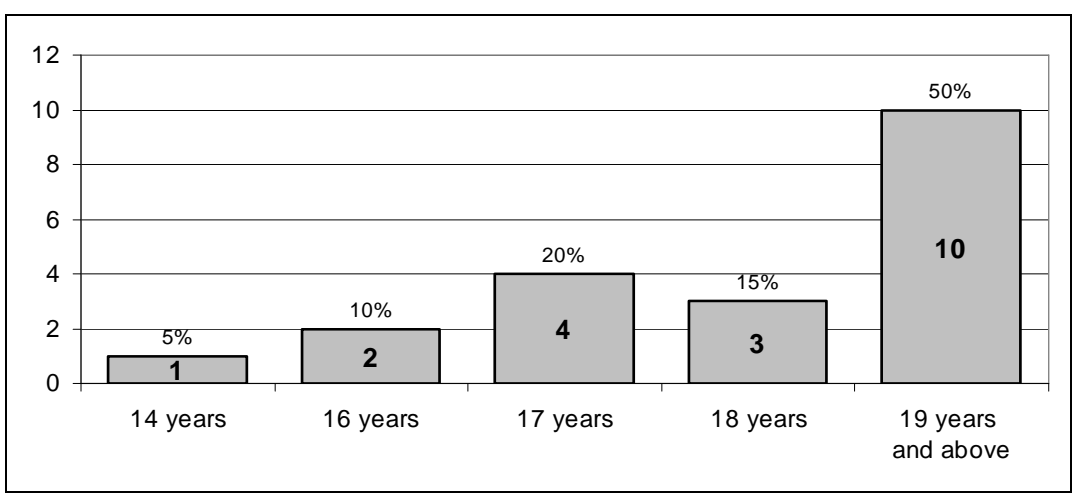

According to the Department of Social Services and Population Development Manual for Places of Safety and Secure Care (2001:48), admission criteria and procedures should be followed with regard to the referral of children or youths to a secure care centre in accordance with the RSA Child Care Act (74 of 1983) and the RSA Criminal Procedures Act (51 of 1977). "Secure care facilities may only accommodate youths from the age 14-17 years" (Department of Social Services and Population Development Manual for Places of Safety and Secure Care, 2001:14). Figure 1 indicates that a significantly high proportion of the respondents $(65 \%)$ were older than 17 years of age and had successfully managed to manipulate the justice system by lying about their ages, since they were detained at a youth secure care centre during the period of the investigation. Only $35 \%$ of the respondents gave their true ages to the justice officials. The various reasons provided by the 
respondents for telling the court that they are younger than they were are explored in the section that discusses the criminal history of the respondents.

Admission of juvenile offenders whose true age is above 20 years has serious behavioural implications for the younger boys, rehabilitation services and for the running of the Centre. Firstly, this exposes the little boys to various forms of abuse (including sexual) by the older boys. Secondly, since some of the older youths have served a prison term or part of a term for their previous offences, they are often familiar with prison culture. They usually influence the younger boys not to participate in the rehabilitation programmes. This makes social treatment of the majority of the juvenile offender population difficult. As a result, most juvenile offenders often miss out on treatment programmes that are designed to rehabilitate them. This seems to contribute to a high rate of recidivism.

On the other hand, it should be noted that the 18-25 age youth category seem to be the most neglected age group in the structures of social services delivery. The neglect of this age group not only applies to young people in conflict with the law, but also those who are "at risk" in various deprived communities. By law, this age group of young people cannot be categorized as children. They are often considered to be young adults. However, these young people are often not ready for adult roles. They are the most vulnerable population group because they are excluded from the structures of social services delivery. Hence they often have to manipulate the social service structures to receive a service for which they would not qualify under strict age criteria.

\section{SUBSTANCE ABUSE}

TABLE 1

FREQUENCY OF SUBSTANCE CONSUMPTION AMONG THE RESPONDENTS

\begin{tabular}{|c|c|c|c|c|c|}
\hline Substance & Frequency & Percentage & Substance & Frequency & Percentage \\
\hline Beer & 15 & 75 & Ecstasy & 3 & 15 \\
\hline Dagga & 14 & 70 & Glue & 2 & 10 \\
\hline Brandy & 13 & 65 & Cocaine & 2 & 10 \\
\hline Ciders & 12 & 60 & $\mathrm{Ndanda}^{2}$ & 1 & 5 \\
\hline VW $\operatorname{star}^{3}$ & 9 & 45 & Heroine & 1 & 5 \\
\hline Rock $^{4}$ & 8 & 40 & Thinners & 1 & 5 \\
\hline Mandrax & 5 & 25 & Benzene & 1 & 5 \\
\hline Shining Top $^{5}$ & 3 & 15 & & & \\
\hline
\end{tabular}

Table 1 indicates that high consumption of substances included beer $(75 \%)$, dagga (70\%), brandy $(65 \%)$ and ciders $(60 \%)$. These are usually considered as soft drugs, easily accessible and affordable. The infrequently consumed substances which were generally less affordable amongst the respondents included heroine $(5 \%)$, ndanda $(5 \%)$, cocaine $(10 \%)$, ecstasy $(15 \%)$ and shining top (15\%). It should be noted that inhalants like thinners $(5 \%)$, benzene $(5 \%)$ and glue $(10 \%)$ were also consumed less frequently because they were considered degrading by the juvenile respon-

2 Sometimes referred to as "Trap en los": a drug that comes in pill form and is often crushed in order to be smoked with dagga. The pill is consumed at short intervals, since it has brief temporary episodic effects on the brain system when used, hence the drug's name.

3 A drug that comes in a pill form that is a bit larger than an average pill size. It has stars on both sides of the pill and is often mixed with dagga to be smoked.

4 A form of cocaine that looks like small, light-brown 'rocks'. The 'rocks' make a crackling sound when used, hence the drug's name 'crack'.

5 A drug that comes in a bullet-capsule form. Its powder is often mixed with dagga to be smoked. 
dents. "Hard drugs," which were relatively frequently consumed among the respondents even though they are also quite expensive, included Mandrax (25\%), rock (40\%), and VW star (45\%).

The findings on high consumption and abuse of alcohol and drugs among young people in general as reflected in this study are consistent with those of Muntingh (2001) and the South African Community Epidemiology Network on Drug Use (SACENDU) ${ }^{6}$. Among other recurrent reasons young offenders cited in Muntingh's (2001) study on why further offence was committed, five (5) cases reported that they were under the influence of alcohol and four (4) cited "to support drug addiction". The SACENDU July 1996-June 2002 report states that in Gauteng province, which includes the metropolitan areas of Johannesburg and Pretoria, a demand for treatment of young people had increased around treatment centres. In the $54 \%$ of the patients at the 17 treatment centres in Gauteng, the primary substance abused was alcohol, followed by cannabis (24\%), heroin (7\%), cocaine/crack (6\%) and Mandrax (5\%). "The proportion of patients younger than 20 years also remains high in most cities, with between a fifth and a quarter falling into this age group in Gauteng, Cape Town, Durban and PE" (SACENDU, 2002:3).

Substance abuse among juvenile offenders seems to be one of the major problems young people are faced with in general. All respondents confessed to have consumed more than one intoxicating substance at different times in their lives, depending on the availability and affordability at the time of consumption. The findings in this study seem to support a strong relationship between substance abuse and recidivism among young offenders.

As a result of a strong relationship that was identified between substance abuse and committal of crime amongst many young offenders, a drug treatment programme was established at the PROTEM: Magaliesoord Centre in Pretoria. This is a state institution run under the auspices of the Gauteng Department of Social Services and Population Development. It caters for the treatment of alcohol-, drug- and medication-dependent people, and also has a secure care section for youths in conflict with the law in general. The facility is often utilised for the court-mandated treatment of young offenders who have the problem of substance abuse.

\section{SOURCES OF INCOME AND MAINTENANCE}

TABLE 2

SOURCE OF INCOME AND FINANCIAL DEPENDENCE

\begin{tabular}{|l|c|c|}
\hline Source & No. & $\%$ \\
\hline Self-employed by running a tuck-shop & 1 & $5 \%$ \\
\hline Older sister employed and a breadwinner at home & 1 & $5 \%$ \\
\hline Mother (self-employed) & 1 & $5 \%$ \\
\hline Mother through foster-care grants for other children & 1 & $5 \%$ \\
\hline Self: employed full time & 1 & $5 \%$ \\
\hline Mother employed and a breadwinner at home & 2 & $10 \%$ \\
\hline Grandparents, through old age pension grants & 2 & $10 \%$ \\
\hline Both parents (employed full time) & 2 & $10 \%$ \\
\hline Criminal activities & 9 & $45 \%$ \\
\hline TOTAL & $\mathrm{N}=20$ & $100 \%$ \\
\hline
\end{tabular}

6 SACENDU is a research institute that monitors alcohol and drug abuse trends in South Africa. 
Table 2 indicates that a high proportion of the respondents $(45 \%)$ depended on crime for their source of income and survival. Only two respondents (10\%) received financial maintenance from their parents, who were both employed.

Most of the juvenile respondents relied on various sources of income, which may not have been sufficient to meet all their needs. For example: one respondent cited his older sister (5\%); another cited his mother $(5 \%)$, who is the only person employed in the family; and two mentioned their grandparents $(10 \%)$. The family members upon whom the respondents relied for financial maintenance usually have to maintain large families with their limited incomes or monthly pension grants.

The reader is reminded that more than half of the respondents in the research confessed their true age to be 19 years and older. However, a high number (40\%) were still staying with their parents either at home or in a flat (35\%) and a relatively high number of the respondents were living with parents and families. These findings seem to support those by Solomon (2001) in her study focusing on the employment project for the reintegration of ex-prisoners. She found that a significantly high number of the ex-prisoners (68.19\%) did not live independently. They lived with their in-laws, other family members or parents specifically for the purposes of financial and social support.

The findings in this study seem to highlight a heavy reliance on criminal activities to generate an income. The inference can therefore be made that recidivism amongst the juvenile offender population can largely be associated with a lack of adequate and stable financial support from parents and the family. This finding is disturbing because, regardless of other forms of social interventions that can be provided to juvenile recidivists, if they are not helped to secure a stable source of income by legal means, then their continued recidivism is inevitable.

\section{CRIMINAL HISTORIES AND ACTIVITIES}

\section{Age of onset in criminal behaviour}

TABLE 3

AGES OF THE RESPONDENTS ON FIRST ARREST AND THE RECORD OF CRIMES COMMITTED

\begin{tabular}{|l|c|c|c|c|}
\hline $\begin{array}{c}\text { Age on first } \\
\text { arrest }\end{array}$ & $\begin{array}{c}\text { No. of } \\
\text { respondents }\end{array}$ & $\%$ & $\begin{array}{c}\text { No. of previous crimes and arrests } \\
\text { including the current offence and arrest }\end{array}$ & $\%$ \\
\hline 10 years & 2 & $10 \%$ & 13 & $16.88 \%$ \\
\hline 13 years & 3 & $15 \%$ & 9 & $11.69 \%$ \\
\hline 14 years & 5 & $25 \%$ & 16 & $20.78 \%$ \\
\hline 15 years & 8 & $40 \%$ & 33 & $42.86 \%$ \\
\hline 16 years & 1 & $5 \%$ & 2 & $2.60 \%$ \\
\hline 18 years* & 1 & $5 \%$ & 4 & $5.19 \%$ \\
\hline TOTAL & $\mathrm{N}=20$ & $100 \%$ & $\mathrm{~N}=77$ & $100 \%$ \\
\hline
\end{tabular}

Table 3 shows that the most frequent age at which the respondents began their criminal careers was 15 years $(40 \%)$. The minimum age of the respondents during their first arrest was 10 years (10\%). The maximum age of the respondent during first arrest was 18 years $(5 \%)$. This respondent confessed that he was in fact 22 years old during the period of investigation and that he was 18 years old when he was first arrested. 
The average age at which the respondents began their criminal careers was 15 years. A significant number had been 13 years old during their first arrest. The findings of this study indicate a relationship between early age first arrest and chronic delinquency amongst young offenders, as have those of other writers, including Barlow and Ferdinand (1992) and Hamparian, Schuster, Dinitz and Conrad (1978).

Contrary to the proposition of Masters (1994) that, as young offenders mature, many outgrow their delinquency as they begin to take on responsibilities, this study found that a large number of respondents continued to rely on criminal activities to make a living, even though they had assumed adult responsibilities. One respondent, 19 years of age, whose mother was serving a prison term during the period of investigation, had the longest history of a criminal record from the entire sample. He had already committed more than four offences and was awaiting trial for the fifth time.

\section{Progression and specialisation}

Barlow and Ferdinand (1992) identified "progression" and "specialisation" as two issues of concern in understanding chronic delinquency. It is generally assumed that juvenile offenders do not start out committing serious offences, but, rather start off with minor offences and progress to serious offences as they extend their juvenile criminal activities. Added to that is the question as to whether juvenile offenders tend to specialise in certain kind of offences as they develop their criminal activities.

\section{FIGURE 2}

\section{CRIMES FOR WHICH THE RESPONDENTS HAD PREVIOUSLY BEEN ARRESTED AND THOSE FOR WHICH THEY HAD CURRENTLY BEEN ARRESTED}

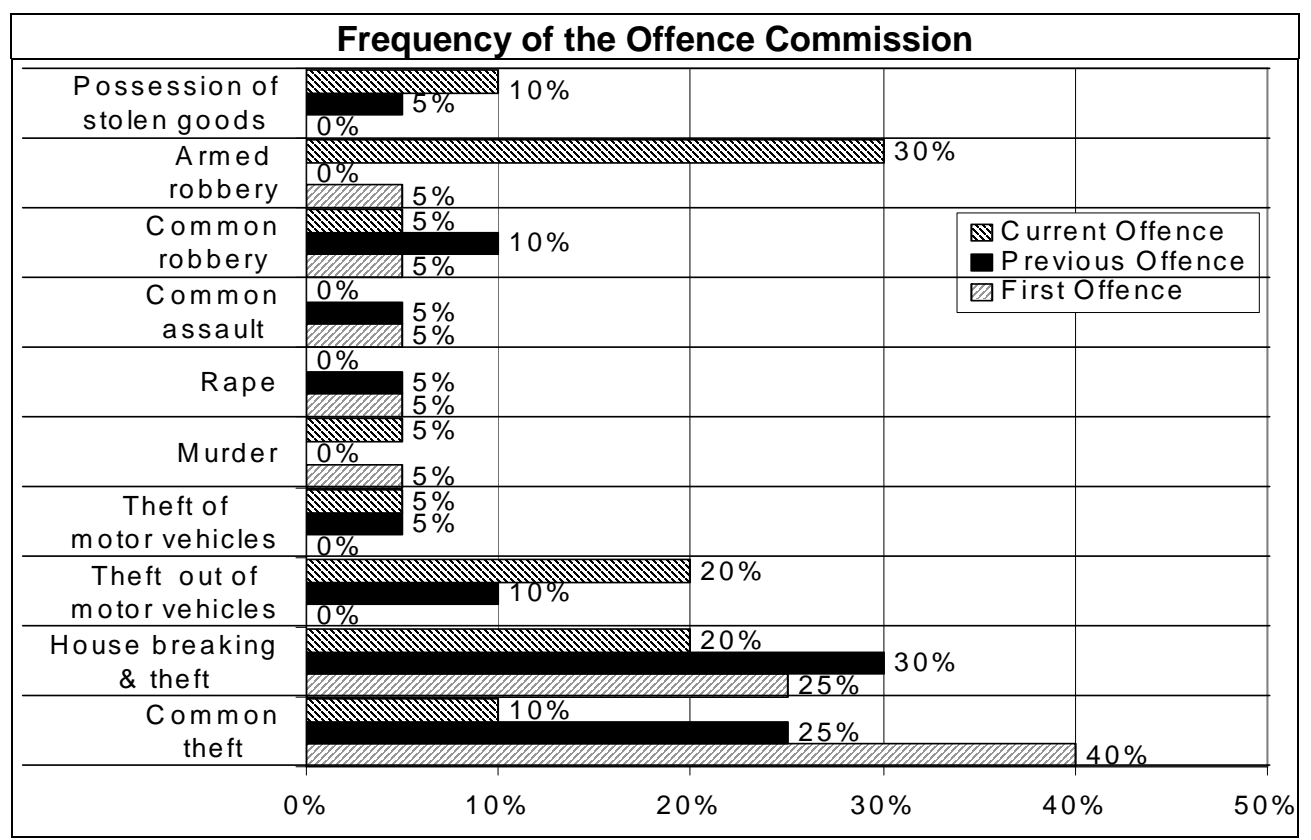

The most frequent criminal offences the respondents started committing in their careers of criminal activities and for which they had been arrested for the first time were property crimes, 
mainly shoplifting (common theft) (40\%), and housebreaking (25\%). Common theft (shoplifting) remained the second most frequent $(60 \%)$ criminal offence the respondents were arrested for in their general criminal histories. Very few individual respondents started their criminal careers with very serious crimes. For instance, of the twenty respondents none started with theft of a motor vehicle; only one (5\%) started with armed robbery; only one $(5 \%)$ started with rape; and only one $(5 \%)$ started with murder. Whilst common theft (40\%), and housebreaking and theft $(25 \%)$ were the most frequent offences the juvenile respondents had started with in their criminal careers, these crimes had decreased as their criminal careers progressed. Instead, the most frequent crimes that the respondents were most commonly arrested for during the period of this investigation were more serious crimes. Common theft had reduced by $30 \%$ and housebreaking had reduced by $5 \%$. The crimes that the respondents were most commonly arrested for during the period of this investigation were armed robbery (30\%); housebreaking and theft (20\%); and theft of a motor vehicle $(20 \%)$.

The findings in this study seem to support the view that "young offenders do not start out committing serious crimes but, rather, they move (progress) from minor to major offences as their involvement in delinquency grows" (Barlow \& Ferdinand, 1992:66). In support of the findings in this study, the American National Youth Survey (Elliot, Huizinga \& Morse cited in Barlow \& Ferdinand, 1992) found that youths who are admitted for persistent offending in any given state, almost half (44\%) increased their involvement and moved to a higher level of seriousness and remained like that from year to year.

Muntingh (2001:50) concluded in his study that "( $\mathrm{t}$ )here appears to be a fair amount of offence specialisation and the majority of recidivists again committed property offences". In contrast, the findings in this study showed a general trend of progression from petty crimes to more serious crimes. It can be inferred from the findings of this study that "offence specialisation is the exception rather than the rule, even among persistent recidivists", as pointed out by Barlow and Ferdinand (1992:65). This means that persistent juvenile offenders will commit any kind of criminal offence randomly at any given time without necessarily preferring certain crimes to the others.

The findings in the research revealed that the period which the respondents spend in detention undergoing rehabilitation in a secure care facility does not necessarily deter the young person from engaging in future criminal activities. However, they do show a possible relationship between a lighter sentence in previous case(s) and subsequent recidivism amongst young offenders. This is one of the clearest common patterns identified in the criminal history of the respondents.

\section{SOCIAL WORK SERVICES AND PREVIOUS REHABILITATION PROGRAMMES}

\section{Relationship with social workers and respondents' evaluation of their services}

The findings show that most of the respondents $(65 \%)$ generally seem to have had a good relationship with the social workers at DYC. It would seem that the social workers were perceived and rated in accordance with the social services that the respondents received or did not receive from them. Those who received some help from the social workers rated their services positively and those who did not receive help rated their services negatively. The ultimate help that most of the juvenile offenders want from the social workers is a good progress report that will convince the court that they have made good progress during their detention in the Centre and are ready for re-integration into the community. Interventions that are focused on and limited to the individual client may eventually prove ineffective, since juvenile offenders desperate to be released will often 
fake an insight into their criminal behaviour. If juvenile offenders are returned to the community without adequate rehabilitation, social workers and probation officers are contributing towards the recidivism of juvenile offenders. Therefore, in an attempt to reduce chances of recidivism, social work interventions and probation services should not only emphasise rehabilitation but also need to incorporate interventions with the families and the communities to which juveniles are returned.

FIGURE 3

NATURE OF RELATIONSHIPS THE RESPONDENTS HAD WITH THE DYC SOCIAL WORKERS

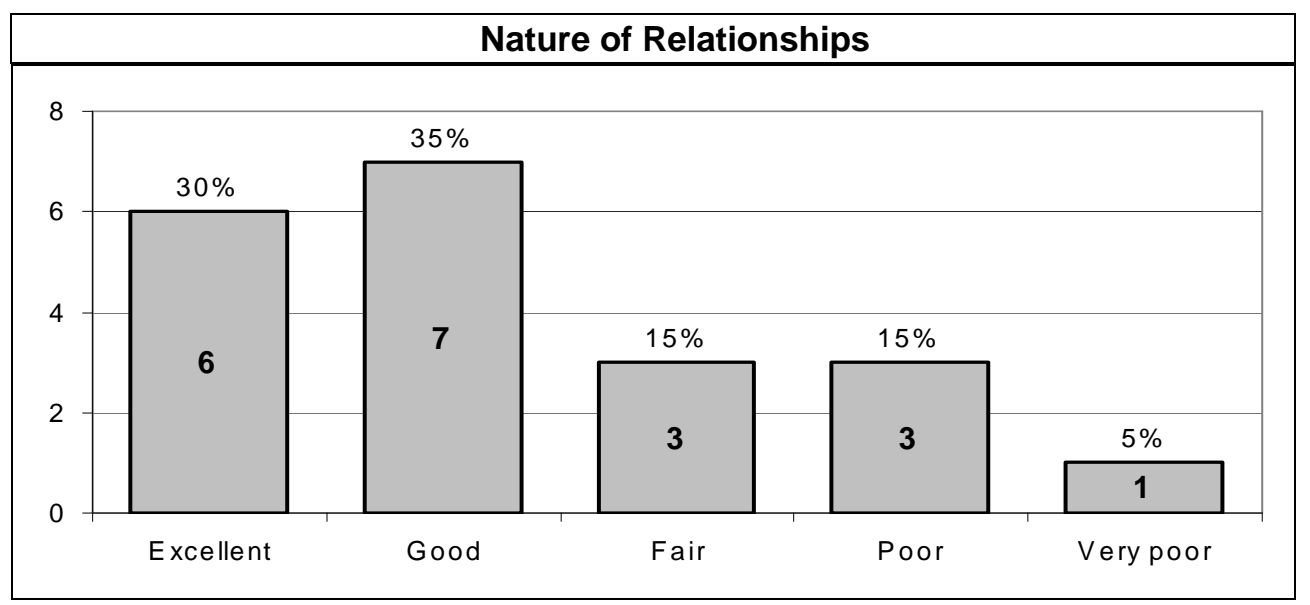

Skills training and personal developmental programmes

TABLE 4

EVALUATION OF SKILLS AND KNOWLEDGE GAINED DURING PREVIOUS DETENTION AT DYC

\begin{tabular}{|l|c|c|c|c|}
\hline & \multicolumn{2}{|c|}{ Most useful } & \multicolumn{2}{c|}{ Least useful } \\
\hline Class or workshop & No. & $\%$ & No. & - \\
\hline Computer training workshop & 5 & $22.72 \%$ & - & -2 \\
\hline Life skills class & 4 & $18.18 \%$ & $10.52 \%$ \\
\hline Arc-welding workshop & 3 & $13.63 \%$ & 1 & $5.26 \%$ \\
\hline Wood work & 3 & $13.63 \%$ & - & - \\
\hline Arts and craft & 3 & $13.63 \%$ & 3 & $15.78 \%$ \\
\hline Electrical training workshop & 1 & $4.54 \%$ & - & - \\
\hline Motor mechanic training workshop & 1 & $4.54 \%$ & - & - \\
\hline Catering training workshop & 1 & $4.54 \%$ & - & - \\
\hline Chapel & 1 & $4.54 \%$ & 1 & $5.26 \%$ \\
\hline None & - & - & 12 & $54.54 \%$ \\
\hline TOTAL & $\mathrm{N}=22 *$ & $100 \%$ & $\mathrm{~N}=19 * *$ & $100 \%$ \\
\hline
\end{tabular}

* The total number is greater than the number of respondents as some of the respondents specified more than one workshop or class.

** The total number is less than the number of the respondents since one of the respondents chose not to respond to the question. 
The findings indicate that respondents generally seem to have acquired very useful knowledge and skills from various rehabilitation programmes during their stay at DYC, since over half of them reported that they found nothing they had learnt at DYC to be least useful when they were in the community. Therefore, if knowledge and skills that they had acquired from various rehabilitation programmes did not reduce recidivism, other factors are likely to have played a role in the high rate of recidivism. These other factors are explored in the section that follows.

\section{MOTIVATION TO RE-COMMIT CRIME}

\section{REASONS GIVEN WHY FURTHER OFFENCE(S) WAS COMMITTED}

\begin{tabular}{|l|c|c|}
\hline Reasons: & No. & $\%$ \\
\hline "The usual way of making money for me and my friends" & 9 & $22.5 \%$ \\
\hline Wanting to wear same stylish clothes as friends & 7 & $17.5 \%$ \\
\hline Helping to bring food home & 7 & $17.5 \%$ \\
\hline Wanting to please my girlfriend & 5 & $12.5 \%$ \\
\hline Money to buy drugs because of addiction & 5 & $12.5 \%$ \\
\hline Means of generating income to pay the child's maintenance & 2 & $5 \%$ \\
\hline To gain approval and a sense of belonging amongst my friends & 1 & $2.5 \%$ \\
\hline Forced by circumstances when I need money desperately & 1 & $2.5 \%$ \\
\hline Helps me gain financial security & 1 & $2.5 \%$ \\
\hline Helps with money to have nice time at the Discos & 1 & $2.5 \%$ \\
\hline "I do not do crime" & 1 & $2.5 \%$ \\
\hline TOTAL & $\mathrm{N}=40 *$ & $100 \%$ \\
\hline
\end{tabular}

* The number is higher than the total number of respondents because several gave more than one reason.

The above table indicates that:

- A high proportion of the respondents (40\%) were motivated mainly by personal financial gain and wanting to satisfy their own interests and wants. These include: a "usual way of making money with friends" $(22.5 \%)$; drugs $(12.5 \%)$; personal financial security $(2.5 \%)$; raving in the discos (2.5\%);

- A sizeable number of respondents (20\%) were motivated by factors associated with financial need and destitution that drove them to become involved in criminal activities. Needs included: food for their home $(12.5 \%)$; maintenance of their children $(5 \%)$; and domestic financial circumstances $(2.5 \%)$;

- A significant number of respondents $(32.5 \%)$ were motivated, probably unconsciously, by factors relating to social and peer pressure to become involved in criminal activities. These included wanting to wear stylish clothes $(17.5 \%)$, wanting to please a girlfriend $(12.5 \%)$, and to gain approval and a sense of belonging among friends $(2.5 \%)$.

The findings on financial need and gain are consistent with the report of TRENDS: PROTEM DETENTION CENTRE (Department of Social Services and Population Development, 20012002:8), which states that "Financial gain in the form of crime-committal is the highest amongst youth. In November/December 2001 more than $82 \%$ of youth admitted at Protem were charged with scheduled offences, e.g. murder, armed robbery and rape". Similarly, it would seem that the respondents committed property-related crimes mainly out of financial need and poverty. 
The literature and findings discussed above seem to indicate that financial need and gain play a significant role in recidivism amongst young offenders. Young people are generally preoccupied with gratification of material needs. In the light of unemployment amongst young people and scarce financial resources, crime is often seen as a viable solution in meeting their otherwise unmet needs.

\section{SOLIDARITY WITH FRIENDS AND PEER PRESSURE}

TABLE 6

THE NATURE OF RELATIONSHIPS THE RESPONDENTS HAD WITH FELLOW INMATES DURING THEIR PREVIOUS DETENTION AT DYC.

\begin{tabular}{|l|c|c|c|c|}
\hline & \multicolumn{2}{|c|}{ Most caring relationship with } & \multicolumn{2}{c|}{ Poorest relationship with } \\
\hline Juvenile & No. & $\%$ & No. & $\%$ \\
\hline Co-accused & 4 & $20 \%$ & 2 & $10 \%$ \\
\hline Room leader & 4 & $20 \%$ & 5 & $25 \%$ \\
\hline Workshop/class mate & 2 & $10 \%$ & - & - \\
\hline Home boy & 8 & $40 \%$ & 2 & $10 \%$ \\
\hline Juvenile inmate just met & 1 & $5 \%$ & 1 & $10 \%$ \\
\hline Gang leader & - & - & 6 & $30 \%$ \\
\hline None & 1 & $5 \%$ & 4 & $20 \%$ \\
\hline TOTAL & $\mathrm{N}=20$ & $100 \%$ & $\mathrm{~N}=20$ & $100 \%$ \\
\hline
\end{tabular}

Table 6 indicates that:

- Nearly half (40\%) of the respondents had only had a good relationship with the inmates who came from the same township as themselves;

- About one third $(30 \%)$ had experienced the poorest relationship with juvenile inmates who were gang leaders;

- The number of respondents who had had poor relationships with room leaders was relatively larger $(25 \%)$ than those who had a caring relationship with the juveniles who were room leaders $(20 \%)$.

The findings on relationship with the room leaders raise concerns that may need to be reviewed by the organisation where research was conducted. A room leader is a juvenile inmate who is democratically elected by the juveniles, together with the staff member, into the position and acts like a prefect in the normal mainstream schooling system. If a quarter of the respondents had experienced a poor relationship with the room leader, this raises questions with regard to the conduct of the room leaders. Possibly some room leaders may have abused the power invested in them to intimidate and oppress other fellow detainees in the rooms instead of providing support and counselling to their roommates.

It is a matter of great concern that about one third of the respondents (30\%) cited gang leaders as the fellow inmates with whom they had the poorest relationships. This finding indicates the presence of a culture of gangsterism amongst juvenile inmates in the secure care centres. It is a subtle form of social interaction amongst the juveniles based on the principles of control and subordination amongst various sub-groups in the Centre. This form of social interaction among sub-groups of juvenile inmates usually goes on undetected until it has blown into a huge fight between two or more rival groups. 
The culture of power, fear and control amongst juvenile offenders usually drives the juvenile detainees to seek protection from other detainees and to establish support groups based on what could be called "cycles of recidivism". This refers to familiarity with each other and social relationships having been established during previous detentions in the same secure care centres.

Certain social support structures amongst juvenile inmates are based purely on the notion that they need to stick together since they come from the same township. A high proportion (40\%) of the respondents had had a good relationship only with other juveniles who came from their township. These groups often end up operating like the gangs that they try to oppose. In certain instances, the juveniles are pressurised to simply join the gangs on the principle of "if you can't beat them, join them and you will be protected".

It can be inferred from the above that most of the juveniles will establish social support networks and relationships that can provide protection for them from abuse by other juveniles and give them a sense of belonging, especially those who have poor relationships with their families. Even though these social support networks may serve a good purpose for the juveniles who may have been disowned by their families, they can also have an adverse impact. Some youngsters may have a stronger sense of belonging to other juveniles' sub-groups than they have with their families when they are in the community. As a result, recidivism and detention can have a positive benefit for them.

The study revealed that peer pressure is one factor that cuts across other various variables that contributed significantly to young peoples' recidivism and resistance towards their rehabilitation. Just over a half $(55 \%)$ of the respondents had been co-accused with friend(s) in the cases that they were arrested for during the period of investigation. The findings in the study support "encouragement by, and solidarity with, mates" and "social and peer pressure" as a second major category motivating juvenile offenders to become constantly involved in delinquent activities. Muntingh (2001:47) also found that "influenced by friends/gangs" was the second major reason presented by 19 youth respondents to the variable "why further offence was committed?" in his longitudinal evaluation of diversion programmes study.

Solidarity with friends often has devastating effects on the rehabilitation of youth offenders who are awaiting trial in a secure care facility. In the researcher's experience of working with juvenile offenders in a secure care facility certain children, although a minority, tend to be highly selfmotivated to participate in the therapeutic programmes, scholastic development classes and workshops, which the majority tend to resist. The resistance towards therapeutic interventions can, in some instances, be attributed to the fact that they have been falsely accused on the charges that have brought them to the Centre. Resistance towards school is usually associated with the fact that some of the youngsters have either never been to school or dropped out of school some time prior to their arrest.

Some of the children and youths have long histories of criminal activities and great experience of interaction with the justice system and detention facilities. Others are new and very unfamiliar with the criminal justice system. Some juvenile detainees adopt a prison mentality and will not participate in any scholastic or rehabilitation programmes. They will often maintain that attending the rehabilitation and scholastic programmes will not make any difference for them, since they are awaiting sentencing and they will eventually be sentenced anyway. These inmates usually have a profound sense of hopelessness and usually have the capacity to influence other juvenile inmates negatively, proclaiming that they are not interested in attending classes because, using their language, "Siboshiwe!", a Zulu word meaning that "We are arrested!" - implying "Leave us alone". 


\section{RE-INTERGRATION INTO THE COMMUNITY AFTER PREVIOUS RELEASE FROM DETENTION}

Although their families and communities received some of the respondents in a positive way $(52.5 \%)$, a significant number experienced rejection $(17.5 \%)$ and isolation $(7.5 \%)$. They felt highly unwanted $(22.5 \%)$ by their different families and communities. This finding pointed to an emerging pattern common to a number of families who viewed the incarceration of their problematic children as a good solution. This trend has been documented in the Protem Detention Centre: Trends report (Department of Social Services and Population Development, 2001-2002), where it is further stated that some parents will not even attend the court hearings so that the duration of the child's custody will be prolonged.

The factors that had made re-integration difficult for the respondents during their previous release were the lack of a stable source of income, denial of re-admission to school, rejection by family and friends, and the lack of stable accommodation. These factors should perhaps be considered as the primary focus of rehabilitation and after-care services in order to reduce recidivism amongst young offenders. The importance of social support for young offenders in their re-integration into the community has best been described by Shearar and Graser (2005). They assert that "Youth stigmatized by their past offences feel that, if they are not accepted in the community, crime is their only option. Communities ultimately put themselves more at risk if they are not involved in providing proper guidance for children" (Shearar \& Graser, 2005:161).

\section{CONCLUSION}

Recidivism amongst young offenders is a significant social problem with many facets, as shown in this study. The study has helped to unravel some of the underlying causes beneath the symptomatic recidivist behavioural pattern among young offenders. Therefore, all strategies that seek to address the problem will need an integrated approach. Some of the young people seemed to be vulnerable and predisposed to criminal behaviour because of their psycho-socio-economic and family backgrounds. Adopting criminal means of survival is common with these young people, even though they are generally aware of the negative consequences of their anti-social behaviour.

Contrary to the notion expressed by Fine (1996) that "nothing matters" to the persistent young offenders, the respondents in this study actually expressed their concern about various matters, including the embarrassment and shame that they caused their families. However, they needed help with regard to long-term social and economic sustainability. Addiction to drugs was one of the major driving forces that had driven the recidivists to constant involvement with crime. Therefore, drug rehabilitation is an essential part of intervention for these juvenile offenders.

Those who work as helping professionals need to mobilise and advocate for transformation even in the broader and social macro structures like the institutions that provide services and policies that inform practice with young people in conflict with the law. The justice system needs to move more towards an approach of restorative justice in dealing with young offenders. The study has shown that prevention and after-care services for young offenders are almost non-existent. Intervention strategies and programmes should address core and underlying issues behind persistent criminal behaviour in young people. These would include implementing intervention strategies and programmes that can ensure the family's social and economic well-being, preventative and treatment programmes regarding alcohol and drug rehabilitation, and specialised training and professional service delivery in the field of young people in conflict with the law. 


\section{RECOMMENDATIONS}

In view of the key findings of the study, outlined below are specific recommendations for prevention and efficient management of recidivism among male awaiting-trial youth offenders and youths in general.

Age

The age of each juvenile offender needs to be established at court. This should form part of the core function of the court officials, rather than of the secure care centre. There needs to be a central computer database at the courts, with a record of the age of each juvenile offender who comes into contact with the criminal justice system.

Partnership between the government, NGOs and private companies that work with young people in conflict with the law, such as NICRO and BOSASA, need to approach private and public companies to create job opportunities for young ex-offenders. This applies especially to young people in the age group of 18 and 25 years, who are usually out of school and have assumed adult roles and responsibilities and lack economic support.

\section{Good practice}

General social work interventions for young offenders - both from probation officers and secure care facilities - should include family intervention and family preservation programmes during both pre-and post-trial statutory phases of the court inquiry.

Reintegration and after-care services for young ex-offenders should form an integral part of probation and social work service delivery. Halfway houses may be necessary for young exoffenders who might need accommodation while being helped to get their lives back on track.

\section{Prevention}

Taking into account that major intervention strategies focus on young people who have already come into contact with the criminal justice system and that they remain in the system for a long period, there needs to be a shift in helping to prevent other young people from coming into contact with the criminal justice system. Crime prevention programmes need to be established in schools through school talks, and in the community through awareness programmes, particularly for those youngsters who are more predisposed to criminal behaviour in the "criminogenic" communities.

Primary and secondary levels of crime prevention are clearly essential in alerting the youth to the far-reaching consequences of coming into contact with the criminal justice system.

\section{Substance abuse}

Young people need to be sensitised to the consequences of substance abuse though awareness and prevention programmes in schools and in public and social gatherings by organisations like SANCA and Drugwise.

Drug and alcohol abuse rehabilitation programmes should form a major part of early treatment and intervention in the services provided for young people in conflict with the law; association with drugs and alcohol often result in participation in criminal activities.

\section{Reintegration}

Families and communities need to support young ex-offenders who want to start a new way of life, rather than rejecting and stigmatising them. Acceptance was one of the crucial factors that the respondents declared for effective reintegration into the community. Probation officers and 
residential social workers need to advocate acceptance by their families through family conferences and family preservation programmes.

Schools need to be sensitised through awareness programmes by probation officers and secure care centre residential social workers on how they often contribute to recidivism amongst young offenders. Schools should be encouraged to re-admit young ex-offenders who want to continue their schooling rather than simply denying them re-admission and labelling them.

\section{REFERENCES}

BAPTISTA, D. \& WOOD, C. 2002. Evaluating the SAYStOP Diversion Programme: Findings from the first follow-up study. Institute of Criminology, University of Cape Town: Unpublished Report, SAYStOP Consortium.

BARLOW, H.D. \& FERDINAND, T.N. 1992. Understanding delinquency. New York: Harper Collins Publishers.

BECK, R. 2001. Recidivism: A fruit salad concept in the criminal justice world. Available: www.justiceconcepts.com/recidivism.htm. [Accessed: 26.07.2006].

BERG, J. 2004. Evaluating the SAYStOP Prevention Programme: Preliminary Findings August-October 1004. Institute of Criminology, University of Cape Town: Unpublished Report, SAYStOP Consortium.

BRENDTRO, L.K., BROKENLEG, M. \& VAN BOCKERN, S. 1990. Reclaiming youth at risk: Our hope for the future. Bloomington, Indiana: National Education Service.

BROWN, M. \& PRATT, J. (eds) 2000. Dangerous offenders: Punishment and social order. New York, Routeledge.

BROWNS, S., McDOWELL, L. \& RACE, P. 1995. 500 Tips for research students. London: Kogan Page Limited.

CONKLIN, J.E. 1995. Criminology. (5 $5^{\text {th }}$ ed). New York: Allyn and Bacon Publishers.

COOPERSMITH, S. 1967. The antecedents of self-esteem. San Francisco. W.H. Freeman.

COPAS, J. \& MARSHALL, P. 1998. The Offender Group Reconviction Scale; a statistical reconviction score for use by probation officers. Applied Statistics (Part 1) 47:159-171.

CURTIS, S. 1989. Juvenile offending: Prevention through intermediate treatment. London: B.T. Batsford Ltd.

DE JONG, C. 1997. Survival analysis and specific deterrence: integrating Theoretical and Empirical models of recidivism. Criminology, 35(4):561-575.

DE VOS, A.S. (ed) 1998. Research at grass roots level. A primer for the caring profession. Pretoria: J.L. van Schaik Publisher.

DEPARTMENT OF SOCIAL SERVICES AND POPULATION DEVELOPMENT. 2001. MANUAL FOR PLACES OF SAFETY AND SECURE CARE. Gauteng Provincial Government.

DEPARTMENT OF SOCIAL SERVICES AND POPULATION DEVELOPMENT. 2001-2002. PROTEM DETENTION CENTRE: TRENDS Report. Gauteng Provincial Government: Magaliesoord Centre: Pretoria. 
ELDEFONSO, E. \& HARTINGER, W. 1976. Control, treatment and rehabilitation of juvenile offenders. London: Collier Macmillan Publishers.

FERRARA, M.L. 1992. Group counseling with juvenile delinquents: The limit and lead approach. Newbury Park, California: Sage Publications.

FINE, N. 1996. A journey through the walls-transforming institutional thinking. Community Law Centre. Bellville: University of Western Cape.

GENDREAU, P. \& ROSS. R.R. 1984. Correctional treatment: Some recommendations for affective treatment. Juvenile and Family Court Journal, 34:31-39.

GRINNELL, R.M. 1993. Social work research and evaluation $\left(4^{\text {th }}\right.$ ed). Itasca: Illinois, Peacock Publishers.

HAMPARIAN, D.M., SCHUSTER, R., DINITZ, S. \& CONRAD, J.P. 1978. The violent few. Lexington, Mass.: D.C. Heath.

LARGAN, P.A. \& LEVIN, D.J. 2002. Recidivism of prisoners released in 1994. Bureau of Justice Statistics Special Report. June, NCJ 193427:1-16.

LESSER, D. \& BRASWELL, M. 1987. Correctional counseling. Cincinnati, OH: Anderson.

MALTZ, M.D. 2001. Recidivism. Orlando: Academic Press, Inc.

MARTINSON, R. 1974. What works? Questions and answers about prison reform. Public Interest, 35:22-54.

MASTERS, R.E. 1994. Counseling criminal justice offenders. California: Sage Publications.

McGUIRE, J. (ed) 1995. What works: Reducing reoffending - guide from research and practice. New York: John Wiley \& Sons.

MUNTINGH, L.M. 2001. The effectiveness of Diversion Programmes - A longitudinal evaluation of cases. Cape Town: NICRO.

PRINSLOO, J.H. 1995. Die aard en omvang van Residivisme in Suid-Afrika aan die hand van bekende gevalle. Pretoria: University of South Africa. (Ongepubliseerde verhandeling vir die Kriminele Rekord Sentrum (SAPD))

RSA. 1997. White Paper for Social Welfare. Government Gazette. Pretoria: Government Printer.

RSA. Child Care Act 74 of 1983. Government Gazette. Pretoria: Government Printer.

RSA. Criminal Procedures Act 51 of 1977. Government Gazette, Pretoria: Government Printer.

SACENDU. 2002. Research Brief, Vol 5 (2b), Monitoring alcohol and drug abuse trends in South Africa (July 1996-June 2002). Medical Research Council of South Africa: University of Durban-Westville.

SCHOEMAN, M.I. 2002. A classification system and an inter-disciplinary action plan for the prevention and management of recidivism. Pretoria: University of Pretoria. (PhD Thesis)

SHEARAR, A. \& GRASER, R. 2005. A critical view of diversion programmes in context of restorative justice. Social Work/Maatskaplike Werk, 41(2):155-162. 
SHERMAN, L., GOTTFREDSON, D., MacKENZIE, D., ECK, J. \& BUSHWAY, S. 1998. Preventing crime: What works, what doesn't, what's promising. Washington, DC: National Institute of Justice.

SOLOMON, S. 2001. An employment project towards reintegration of ex-prisoners. Cape Town: University of Cape Town. (M thesis)

THOMPSON, W.E. \& BYNNUM, J.E. 1991. Juvenile delinquency: Classic and contemporary readings. New York: Allyn \& Bacon.

TRIPODI, T., FELLIN, P. \& MEYER, H. 1972. The assessment of social research, guidelines for use of research in social work and social science $\left(2^{\text {nd }}\right.$ ed $)$. USA: F.E. Peacock Inc.

WEST, D.J. \& FARRINGTON, D.P. 1977. The delinquent way of life. London: Heinemann.

WOOD, C. 2003. Diversion in South Africa: A review of policy and practice, 1990-2003. Cape Town. Institute of Criminology, UCT: Unpublished Occasional Paper 79.

Mr Thulane Gxubane, Lecturer, Department of Social Development, University of Cape Town, Rondebosch, South Africa. 